\title{
Synthesis and Free Radical Scavenging Activity of New Hydroxybenzylidene Hydrazines
}

\author{
Frantisek Sersen ${ }^{1, *, \dagger}$, Fridrich Gregan ${ }^{2,+}{ }^{\text {, Peter Kotora }}{ }^{3}$, Jarmila Kmetova ${ }^{2}$, Juraj Filo ${ }^{1}$, \\ Dusan Loos ${ }^{4}$ and Juraj Gregan ${ }^{5,6, *}$
}

1 Institute of Chemistry, Faculty of Natural Sciences, Comenius University in Bratislava, Ilkovicova 6, 84215 Bratislava, Slovakia; filo@fns.uniba.sk

2 Department of Chemistry, Faculty of Natural Sciences, Matej Bell University, Tajovskeho 40, 97401 Banska Bystrica, Slovakia; frido.gregan@gmail.com (F.G.); Jarmila.Kmetova@umb.sk (J.K.)

3 Institute of Process Engineering, Faculty of Mechanical Engineering, Slovak University of Technology in Bratislava, Namestie slobody 17, 81231 Bratislava, Slovakia; kotora@fns.uniba.sk

4 Department of Organic Chemistry, Faculty of Natural Sciences, Comenius University in Bratislava, Ilkovicova 6, 84215 Bratislava, Slovakia; loosdus@gmail.com

5 Department of Genetics, Faculty of Natural Sciences, Comenius University in Bratislava, Ilkovicova 6, 84215 Bratislava, Slovakia

6 Department of Chromosome Biology, Max F. Perutz Laboratories, University of Vienna, Dr. Bohr-Gasse 9, 1030 Vienna, Austria

* Correspondence: f.sersen@gmail.com (F.S.); juraj.gregan@univie.ac.at (J.G.); Tel.: +421-2-602-96 (ext. 412) (F.S.); +421-2-602-96 (ext. 447) (J.G.); Fax: +421-2-654-29-064 (J.G. \& F.S.)

+ These authors contributed equally to this work.

Academic Editor: Derek J. McPhee

Received: 7 April 2017; Accepted: 26 May 2017; Published: 29 May 2017

\begin{abstract}
Hydroxybenzylidene hydrazines exhibit a wide spectrum of biological activities. Here, we report synthesis and free radical scavenging activity of nine new $N$-(hydroxybenzylidene)$N^{\prime}$-[2,6-dinitro-4-(trifluoromethyl)]phenylhydrazines. The chemical structures of these compounds were confirmed by ${ }^{1} \mathrm{H}-\mathrm{NMR},{ }^{13} \mathrm{C}-\mathrm{NMR},{ }^{19} \mathrm{~F}-\mathrm{NMR}$, IR spectroscopy, LC-MS, and elemental analysis. The prepared compounds were tested for their activity to scavenge 2,2-diphenyl-1-picrylhydrazyl (DPPH), galvinoxyl radical (GOR), and 2,2'-azino-bis(3-ethylbenzothiazoline)-6-sulphonic acid (ABTS) radicals. The free radical scavenging activity expressed as $\mathrm{SC}_{50}$ values of these compounds varied in a wide range, from a strong to no radical scavenging effect. The most effective radical scavengers were hydroxybenzylidene hydrazines containing three hydroxyl groups in the benzylidene part of their molecules. The prepared compounds were also tested for their activity to inhibit photosynthetic electron transport in spinach chloroplasts. $\mathrm{IC}_{50}$ values of these compounds varied in wide range, from an intermediate to no inhibitory effect.
\end{abstract}

Keywords: $N$-(hydroxybenzylidene)-N'-[2,6-dinitro-4-(trifluoromethyl)]phenylhydrazines; radical scavenging activity; DPPH scavenging; GOR scavenging; ABTS scavenging; photosynthetic electron transport

\section{Introduction}

$\mathrm{N}$-Hydroxybenzylidene hydrazines, also known as hydrazones, are $\mathrm{N}$-arylmethylidene$N^{\prime}$-arylhydrazines with a diazamethylidene group $\mathrm{C}=\mathrm{N}-\mathrm{NH}[1,2]$. The fact that $\mathrm{N}$-arylmethylidene$N^{\prime}$-arylhydrazines represent an important class of compounds for new drug development motivates researchers to synthesize and test new $N$-arylmethylidene- $N$-arylhydrazines. These compounds can be prepared from the corresponding aromatic aldehydes and substituted arylhydrazines in alcohol (ethanol, methanol), acetic acid, or another solvents [1,2]. Synthesis without solvents using acidic 
ionic liquids such as choline chloride and oxalic acid has also been reported [3]. The combination of diazamethylene group with other functional groups leads to compounds with interesting physical and chemical characteristics [4].

The synthesis of novel $N$-arylmethylidene- $N^{\prime}$-arylhydrazines and their derivatives is of great interest because of their potential use in the biopharmaceutic industry. These compounds possess various biological and pharmacological properties, including antimicrobial, analgesic, antifungal, anti-tubercular, antiviral, anticancer, antimalarial, antihelmintic, anti-trypanosomal, and antischistosomiasis properties. In addition, $N$-arylmethylidene- $N^{\prime}$-arylhydrazines are used as pigments, dyes, catalysts, ligands in organometallic complexes and polymer stabilizers [5-12]. $N$-arylmethylidene- $N^{\prime}$-arylhydrazines are also important for the synthesis of heterocyclic compounds such as indoles and pyrazoles $[13,14]$. Derivatives of benzylidene hydrazine are potent inhibitors of fungal growth with little mammalian cell toxicity, making them promising new targets for future therapeutic development [1]. Several derivatives of $N$-nitrobenzylidene- $N$-phenylhydrazines exhibit amoebicidal activity with an $\mathrm{IC}_{50}$ of $0.84 \mu \mathrm{M}$, which represents a sevenfold increase in cell growth inhibition potency with respect to metronidazole $\left(\mathrm{IC}_{50}=6.3 \mu \mathrm{M}\right)$ [12]. Several novel 2,4-dinitrophenylhydrazone betulinic acid derivatives showed significant cytotoxicity and selectivity against some tumor cell lines [15]. Due to their strong chemical stability, $N$-arylmethylidene$N^{\prime}$-arylhydrazines are also an attractive material in optoelectronics technologies and development of potential chemosensors, optical switching devices, and organic light emission devices (OLEDs) [16]. However, $N$-arylmethylidene- $N$-arylhydrazines also show adverse effects. Some $N$-arylmethylidene$N^{\prime}$-arylhydrazines induce DNA fragmentation [17] and damage photosynthesis in chloroplasts [18-21].

The main aim of this work was to synthesize new hydroxybenzylidene hydrazines and determine their free radical scavenging activity. We prepared nine new $N$-(hydroxybenzylidene)- $N^{\prime}-$ [2,6-dinitro-4-(trifluoromethyl)]phenylhydrazines with $\mathrm{OH}$ groups at different positions of the benzene ring and analyzed their ability to scavenge 2,2-diphenyl-1-picrylhydrazyl (DPPH), galvinoxyl radicals (GOR), and 2,2'-azino-bis(3-ethylbenzothiazoline)-6-sulphonic acid (ABTS).

\section{Results and Discussion}

\subsection{Chemistry}

All compounds prepared in this study (5a-5i) contain the 2,4-dinitro-4-(trifluoromethyl)phenyl group and an additional hydroxyphenyl group $(5 \mathbf{a}, \mathrm{R}=4$-hydroxyphenyl, $\mathbf{5} \mathbf{b}, \mathrm{R}=2,3$-dihydroxyphenyl, 5c, $\mathrm{R}=$ 2,4-dihydroxyphenyl, $5 \mathbf{d}, \mathrm{R}=$ 2,5-dihydroxyphenyl, $5 \mathbf{e}, \mathrm{R}=3,5$-dihydroxyphenyl, 5f, $R=$ 2,3,4-trihydroxyphenyl, 5g, $R=$ 2,4,6-trihydroxyphenyl, 5h, $R=3,4,5$-trihydroxyphenyl, and 5i, $\mathrm{R}=$ phenyl) (Scheme 1).

The starting compounds for the synthesis of hydroxybenzylidene hydrazines $5 \mathbf{a}-5 \mathbf{i}$ were 2,6-dinitro-4-(trifluoromethyl)phenylhydrazine 3 and aromatic aldehydes $4 \mathbf{a}-4 \mathbf{i}$ (Scheme 1). The starting compound for the preparation of 2-methoxy-1,3-dinitro-5-(trifluoromethyl)benzene 2 (Scheme 1) was 2-chloro-1,3-dinitro-4-(trifluoromethyl)benzene 1. The yield of the compound 2 was $76 \%$, M.p. $61{ }^{\circ} \mathrm{C}$ [22].

For the synthesis of compounds $\mathbf{5 a - 5 i}$, we used trifluoroacetic acid (TFA) as acidic catalyst and ethanol as solvent. The reaction time was $3-4 \mathrm{~h}$, reaction temperatures were $20-25{ }^{\circ} \mathrm{C}$, and yields were $70-85 \%$. The purity of prepared compounds and the course of reactions were monitored by TLC. The crude hydrazines $\mathbf{5 a - 5 i}$ were purified by column chromatography on silica gel in hexane/ethylacetate (4:1) as the mobile phase. All prepared hydroxybenzylidene hydrazines $5 \mathbf{a}-\mathbf{5 i}$ as well as their solutions in organic solvents were dark red. The dark red color changed to dark blue upon the increase in $\mathrm{pH}$, suggesting that these compounds are sensitive to $\mathrm{pH}$. The melting points of these compounds are relatively high $\left(226-280^{\circ} \mathrm{C}\right)$. The chemical structures of prepared compounds were confirmed by ${ }^{1} \mathrm{H}-\mathrm{NMR},{ }^{13} \mathrm{C}-\mathrm{NMR},{ }^{19} \mathrm{~F}-\mathrm{NMR}$, IR spectroscopy, LC-MS and elemental analysis. Elemental analyses agreed with theoretical values $( \pm 0.3)$. The IR spectra revealed several characteristic absorption bands. Two absorption bands were observed in the region stretching $\mathrm{NO}_{2}$ 
vibration. The more intense band appearing at higher wave numbers $\left(1538-1503 \mathrm{~cm}^{-1}\right)$ corresponds to assymetric $\mathrm{NO}_{2}$ vibrations, and the less intense one, appearing at a lower wave number $\left(1279-1257 \mathrm{~cm}^{-1}\right)$, corresponds to symmetric vibrations. The absorption band at $3277-3257 \mathrm{~cm}^{-1}$ corresponds to stretching $\mathrm{N}-\mathrm{H}$ vibrations. The wave number of this absorption band is affected by the mesomeric effect of $\mathrm{OH}$ groups on the benzene ring. The absorption band at $1619-1616 \mathrm{~cm}^{-1}$ corresponds to stretching vibrations in the $\mathrm{C}=\mathrm{N}$ group. The presence of $\mathrm{CF}_{3}$ group in molecules was confirmed by ${ }^{19} \mathrm{~F}_{-}{ }^{13} \mathrm{C}$ splitting to quartet in ${ }^{13} \mathrm{C}$ NMR spectra of corresponding derivatives $\left[4^{\prime}\left(115.82-116.71 \mathrm{ppm},{ }^{2} J=35.1-35.4 \mathrm{~Hz}\right)\right.$; $\left.3^{\prime}, 5^{\prime}\left(127.189-127.72 \mathrm{ppm},{ }^{3} J=3.2-3.5 \mathrm{~Hz}\right) ; \mathrm{CF} 3\left(122.67-123.20 \mathrm{ppm},{ }^{1} J=271.3-271.6 \mathrm{~Hz}\right)\right]$.

The double bond between $\mathrm{C}$ and $\mathrm{N}$ in $\mathrm{C}=\mathrm{N}-\mathrm{NH}$ - group of benzylidene hydrazines allows for the formation of two stereoisomers, namely (E) and (Z). The stereoisomerism of these compounds has not been studied in detail, but we predict that $(\mathrm{E})$ is the more abundant form [2,23].
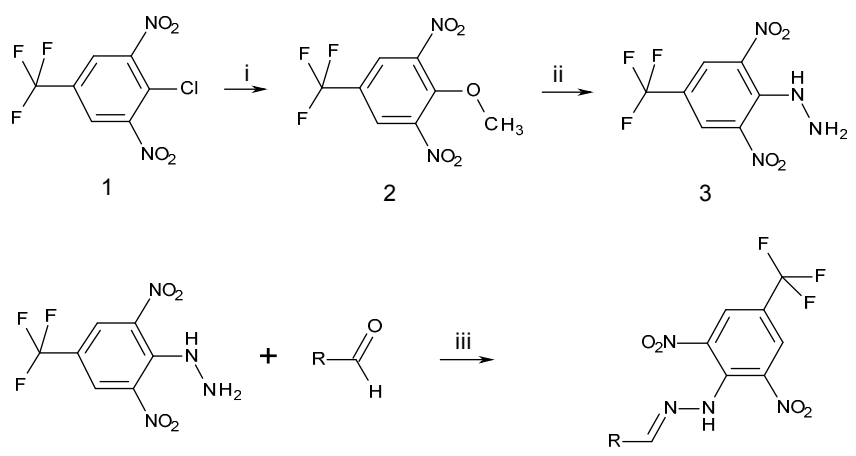

3

$4 a-4 \mathrm{i}$

$5 a-5 i$

Scheme 1. Synthesis of 2,6-dinitro-4-(trifluoromethyl)phenylhydrazine 3 and $N$-(hydroxybenzylidene)$N^{\prime}$-[2,6-dinitro-4-(trifluoromethyl)]phenylhydrazines 5a-5i. 5a $\mathrm{R}=4$-hydroxyphenyl, $5 \mathbf{b} \mathrm{R}=2,3$ dihydroxyphenyl, 5c $\mathrm{R}=$ 2,4-dihydroxyphenyl, 5d $\mathrm{R}=2,5$-dihydroxyphenyl, $5 \mathbf{e} \mathrm{R}=3,5$ dihydroxyphenyl, $5 f \mathrm{R}=$ 2,3,4-trihydroxyphenyl, $5 \mathrm{~g} \mathrm{R}=$ 2,4,6-trihydroxyphenyl, $5 \mathbf{h} \mathrm{R}=3,4,5$ trihydroxyphenyl, 5i $\mathrm{R}=$ phenyl. Reactants and reaction condition: (i) $\mathrm{H}_{3} \mathrm{C}-\mathrm{ONa}$, methanol, room temperature, $1 \mathrm{~h}$; (ii) $\mathrm{H}_{2} \mathrm{~N}-\mathrm{NH}_{2} \cdot \mathrm{H}_{2} \mathrm{O}, \mathrm{EtOH}, 0{ }^{\circ} \mathrm{C}, 1 \mathrm{~h}$; (iii) $\mathrm{EtOH}$, trifluoroacetic acid (TFA), room temperature, $3 \mathrm{~h}$. Structure of all newly prepared compounds was confirmed by ${ }^{1} \mathrm{H}-\mathrm{NMR}$, ${ }^{13} \mathrm{C}-\mathrm{NMR},{ }^{19} \mathrm{~F}-\mathrm{NMR}$, IR spectroscopy, and elemental analysis.

\subsection{Free Radical Scavenging Activity Assay}

$\mathrm{SC}_{50}$ values for scavenging DPPH, GOR, and ABTS radicals are shown in the Table 1 . These results suggest that the majority of studied hydroxybenzylidene hydrazines exhibit free radical scavenging activity. Almost all studied benzylidene hydrazines (with the exception of compound 5i) scavenged ABTS radical in a water solution. The most effective scavengers of ABTS radicals were compounds $\mathbf{5 b}$ and 5e with two $\mathrm{OH}$ groups in positions 2,3 and 3, 5, respectively. Hydroxybenzylidene hydrazines with three hydroxyl groups $(\mathbf{5 b}, \mathbf{5 f}, \mathbf{5} \mathbf{h}$ and $\mathbf{5 g}$ ) also scavenged ABTS radicals. The most effective scavengers of DPPH radicals were hydroxybenzylidene hydrazines with three $\mathrm{OH}$ groups $(\mathbf{5} \mathbf{h}$ and $\mathbf{5 f})$. The molecules with two $\mathrm{OH}$ groups $(\mathbf{5 b}, \mathbf{5} \mathbf{c}, \mathbf{5 g})$ were weaker scavengers of DPPH radicals. Hydroxybenzylidene hydrazine with one $\mathrm{OH}$ group (5a) exhibited very weak scavenger activity, and the compound with $\mathrm{OH}$ groups in positions 3 and 5 (5e) as well as the compound without $\mathrm{OH}$ group (5i) did not scavenge DPPH radicals.

The compound with three $\mathrm{OH}$ groups (5f) in positions 2, 3, and 4 was the most effective scavenger of GOR radicals. The compounds $5 \mathbf{b}, \mathbf{5 d}, \mathbf{5 g}$, and $5 \mathrm{~h}$ exhibited moderate scavenger activity, and the compound $5 \mathbf{a}$ (with one $\mathrm{OH}$ group) exhibited very low activity to scavenge GOR radicals. Similarly as observed with DPPH radicals, the compounds $5 \mathbf{e}$ and $5 \mathbf{i}$ showed no scavenging of GOR.

Taken together, we conclude that molecules with three hydroxyl groups (5b, 5f, and $\mathbf{5 h}$ ) exhibited high free radical scavenging activities. The most effective compound was the compound $\mathbf{5 f}$, 
which contains $\mathrm{OH}$ groups in positions 2, 3, and 4. Interestingly, the compound with no hydroxyl group (5i) showed no scavenging activity. Some of the studied compounds ( $\mathbf{5 f}$ and $\mathbf{5 h}$ ) exhibited higher free radical scavenging activity than that reported for ascorbic acid $\left(\mathrm{SC}_{50}=12.55 \mu \mathrm{mol} / \mathrm{dm}^{3}\right)$ [24], resveratrol $\left(\mathrm{SC}_{50}=26.37 \mu \mathrm{mol} / \mathrm{dm}^{3}\right)$ [25], and esculetin $\left(\mathrm{SC}_{50}=8.64 \mu \mathrm{mol} / \mathrm{dm}^{3}\right)$ [26]. We speculate that the ability to release hydrogen atom or proton from hydroxyl groups of the hydroxybenzylidene hydrazine molecule contributes to the mechanism of radical scavenging of the studied hydroxybenzylidene hydrazines.

Next, we tried to find a possible correlation between free radical scavenging activity and energy necessary for releasing of hydrogen atom or proton. We used the method PM6 (see the Experimental Section) to calculate the energy associated with the release of hydrogen atom (bond dissociation enthalpy, BDE), the proton relaxation (proton dissociation enthalpy, PDE), release of electron (ionization potential, IP), and the energy associated with the combined transfer of the electron and proton (ETE and PA, respectively) for the studied benzylidene hydrazines. The values of these energies in methanol or in water are presented in Tables S1-S8. Figure 1 shows the dependence of $\mathrm{SC}_{50}$ of $\mathrm{DPPH}, \mathrm{GOR}$, and ABTS scavenging on the sum of PA + ETE values and BDE, respectively. The results presented in the Figure 1A,B suggest that the ability of scavenging of DPPH and GOR radicals at higher $\mathrm{BDE}$ and PE + ETE enthalpy decreases-the dependence is almost linear (the square deviation $\mathrm{r}^{2}=0.87$ for DPPH and $r^{2}=0.70$ for GOR). This tendency is confirmed by the fact that the inactive substances (5a and 5e) have the greatest values of BDE and PA + ETE (Table 1). On the other hand, the dependence of the scavenging of ABTS radicals on BDE or PA + ETE shows no dependence (Figure 1C).

Table 1. Antiradical and PET inhibition activities of studied hydroxybenzilidene hydrazines expressed as $\mathrm{SC}_{50}$ and $\mathrm{IC}_{50}$ values, respectively.

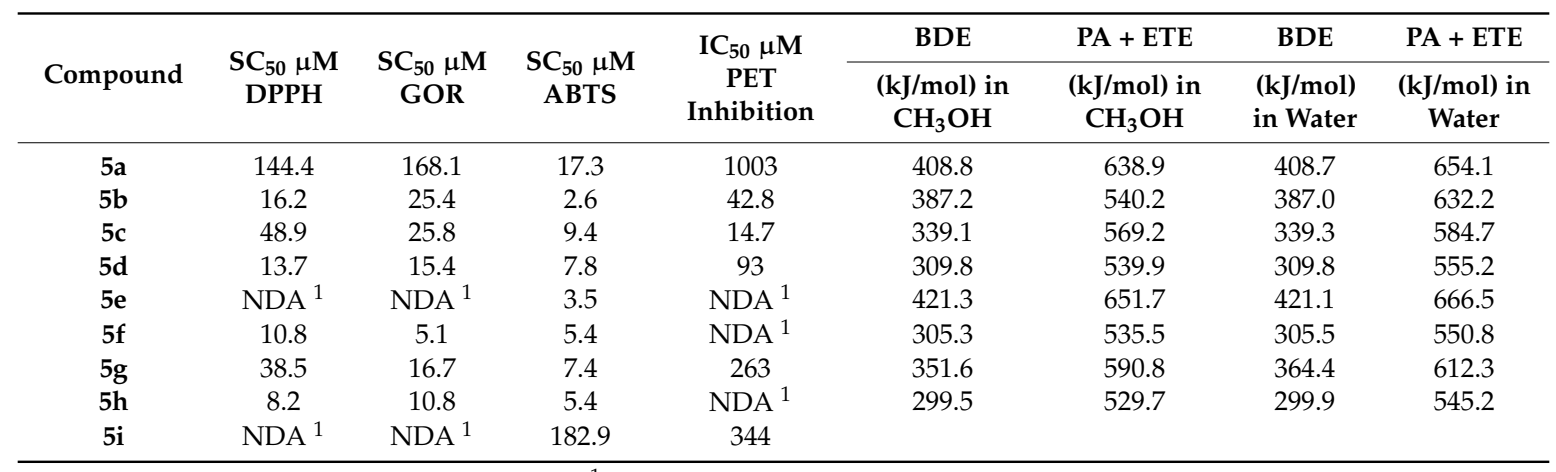

${ }^{1}$ NDA (no detectable activity).
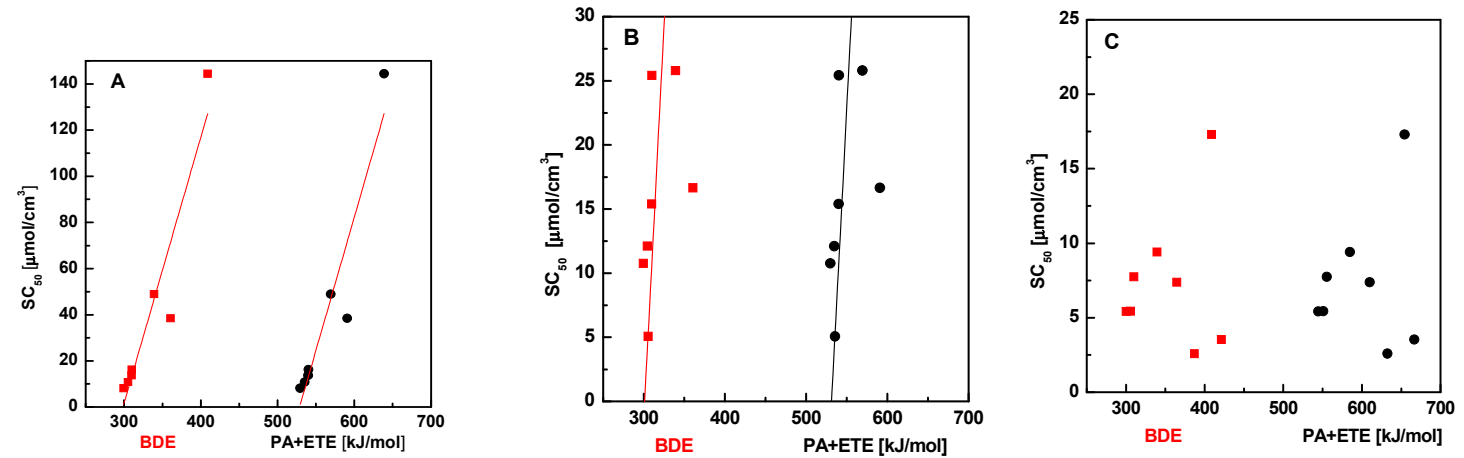

Figure 1. Dependence of $\mathrm{SC}_{50}$ of DPPH (A), GOR (B), and ABTS (C) scavenging on BDE (red squares) or PA + ETE (black circles).

\subsection{Inhibition of Photosynthetic Electron Transport (PET) in Spinach Chloroplasts}

The prepared compounds were also tested for their activity to inhibit PET in spinach chloroplasts. $\mathrm{IC}_{50}$ values of these compounds varied in a wide range, from an intermediate $\left(14.7 \mu \mathrm{mol} / \mathrm{dm}^{3}\right)$ to 
no inhibitory effect (Table 1$)$. The most effective were compounds $5 \mathrm{c}\left(\mathrm{IC}_{50}=14.7 \mu \mathrm{mol} / \mathrm{dm}^{3}\right)$ and $5 \mathrm{~b}\left(\mathrm{IC}_{50}=42.8 \mu \mathrm{mol} / \mathrm{dm}^{3}\right)$. These activities are relatively low as compared to the values reported for the classical herbicide diuron (3-(3,4-dichlorophenyl)-1,1-dimethylurea; DCMU) with an $\mathrm{IC}_{50}$ of $1.9 \mu \mathrm{mol} / \mathrm{dm}^{3}$ [27] and are unlikely to be of industrial interest.

\section{Materials and Methods}

\subsection{General Information}

2-Chloro-1,3-dinitro-4-(trifluoromethyl)benzene 1 (Scheme 1), galvinoxyl free radical (GOR), and organic solvents were purchased from Alfa Aesar (Ward Hill, MA, USA) and used without further purification. 2,2-Diphenyl-1-picrylhydrazyl (DPPH) and 2,2' -azino-bis(3-ethylbenzothiazoline6-sulfonic acid) diammonium salt (ABTS) was purchased from Sigma-Aldrich (St. Louis, MO, USA). Methyl alcohol p.a., TRIS, $\mathrm{MgCl}_{2}$, saccharose and dimethylsulfoxide p.a. (DMSO) were purchased from Centralchem (Bratislava, Slovakia).

Melting points were determined on a Boetius apparatus and are uncorrected. IR spectra were obtained on a NICOLET iS50 FT-IR spectrophotometer using an ATR technique in the region 4000-400 $\mathrm{cm}^{-1}$. Elemental analyses were obtained on an Elemental Analyzer Carlo Erba CHNS-OEA 1108. NMR spectra were performed on a Spectrometer Varian VNMRS $300 \mathrm{MHz}(300 \mathrm{MHz}$ for ${ }^{1} \mathrm{H}, 75 \mathrm{MHz}$ for ${ }^{13} \mathrm{C}, 282 \mathrm{MHz}$ for $\left.{ }^{19} \mathrm{~F}\right)$ and on a Spectrometer Varian VNMRS $600 \mathrm{MHz}(600 \mathrm{MHz}$ for ${ }^{1} \mathrm{H}$ and $150 \mathrm{MHz}$ for ${ }^{13} \mathrm{C}$ ) in DMSO- $d_{6}$, with tetramethylsilane (TMS) as an internal standard. The purity of prepared compounds and the course of reactions were checked on Merck TLC Silica gel $60 \mathrm{~F}_{254}$ plates in ethyl acetate- $n$-hexane as the mobile phase. The numbering of atoms for the evaluation of NMR spectra of measured compounds $\mathbf{3}$ and $\mathbf{5 a} \mathbf{a} \mathbf{- 5 i}$ is given in the formulae. Absorption spectra were recorded by a Genesis 6 spectrophotometer (Thermo-Scientific, Waltham, MA, USA). FTIR spectra (in solid phase) were recorded on a Nicolet 6700 spectrometer (Thermo-Scientific (Nicolet), Waltham, MA, USA) using the ATR technique.

MS spectra were recorded by LC-MS spectrometer consisting of an Agilent 1200 HPLC (Walbron, Germany), with an MSD 6110 MS detector (Agilent Technologies, Santa Clara, CA, USA).

\subsection{Synthesis}

\subsubsection{Synthesis of 2,6-Dinitro-4-(Trifluoromethyl)Phenylhydrazine (3)}

A solution of hydrazine monohydrate $(0.75 \mathrm{~g}, 15 \mathrm{mmol})$ in anhydrous ethanol $(5 \mathrm{~mL})$ was added dropwise to a solution of 2-methoxy-1,3-dinitro-5-(trifluoromethyl)benzene 2 (3.2 g, $12 \mathrm{mmol})$ in anhydrous ethanol $(17 \mathrm{~mL})$ under an argon atmosphere. The reaction mixture was stirred at $0{ }^{\circ} \mathrm{C}$ for $1 \mathrm{~h}$ and monitored by TLC. The solvent was removed under vacuum, and crude product was purified by column chromatography on silica gel in hexane/ethylacetate (4:1) as the mobile phase. This resulted in $2.8 \mathrm{~g}(88 \%)$ of 2,6-dinitro-4-(trifluoromethyl)phenylhydrazine 3 (yellow solid), M.p. $125-126{ }^{\circ} \mathrm{C}$. The previously published M.p. for this compound is $124^{\circ} \mathrm{C}$ [23].

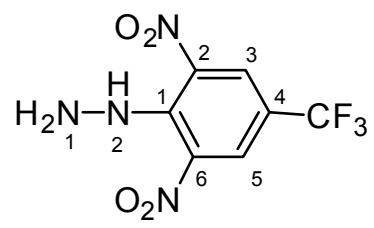

2,6-dinitro-4-(trifluoromethyl)phenylhydrazine (3). Yield 88\%; red solid, M.p. $125-126{ }^{\circ} \mathrm{C}$, Anal. Calcd. for $\mathrm{C}_{7} \mathrm{H}_{5} \mathrm{~F}_{3} \mathrm{~N}_{4} \mathrm{O}_{4}(266.14) \mathrm{C}, 31.59 ; \mathrm{H}, 1.89$ : N, 21.05. Found: C, 31.71; H, 1.74; N, 20.86\%. IR: 3248, $v(\mathrm{~N}-\mathrm{H}) ; 1636, v(\mathrm{C}=\mathrm{N}) ; 1536, v_{\mathrm{as}}\left(\mathrm{NO}_{2}\right) ; 1263, v_{\mathrm{s}}\left(\mathrm{NO}_{2}\right) ; 1118, v\left(\mathrm{CF}_{3}\right) .{ }^{1} \mathrm{H} \mathrm{NMR}(300 \mathrm{MHz}, \mathrm{DMSO}):$ $\delta=9.65$ (s, 1H, NH-2), 8.40 (s, 2H, H-3, H-5), 4.84 (s, 2H, NH-1). ${ }^{13} \mathrm{C}$ NMR (75 MHz, DMSO): $\delta=142.97$, 
136.75, $127.87(\mathrm{q}, J=3.5 \mathrm{~Hz}), 123.32(\mathrm{q}, J=271.0 \mathrm{~Hz}), 113.76(\mathrm{q}, J=35.3 \mathrm{~Hz})$; negative LC-MS $m / z: 265.0$ $[\mathrm{M}-\mathrm{H}]^{-}$calc. for $\mathrm{C}_{7} \mathrm{H}_{4} \mathrm{~F}_{3} \mathrm{~N}_{4} \mathrm{O}_{4}{ }^{-}, 265.018$, found 265.0.

3.2.2. Synthesis of $N$-Hydroxybenzylidene- $N^{\prime}-[2,6$-Dinitro-4-(Trifluoromethyl)]Phenylhydrazines (5a-5h) and $N$-(Benzylidene)-N'-[2,6-Dinitro-4-(Trifluoromethyl)]Phenylhydrazine (5i)

A solution of 2,6-dinitro-4(trifluoromethyl)phenylhydrazine 3 (1 mmol) in ethanol ( $3 \mathrm{~mL})$ was added to a solution of aldehydes $4 \mathbf{a}-4 \mathbf{i}$ in ethanol $(5 \mathrm{~mL})$ and trifluoroacetic acid $(0.5 \mathrm{~mL})$. The reaction mixture was stirred for 3-4 h at room temperature in argon atmosphere and monitored by TLC. The reaction mixture was cooled to $0{ }^{\circ} \mathrm{C}$, and the red solid product was filtered off, washed with ethanol/ether (1:5), and dried. The product was purified by column chromatography on silica gel in hexane/ethylacetate (3:1) as the mobile phase.

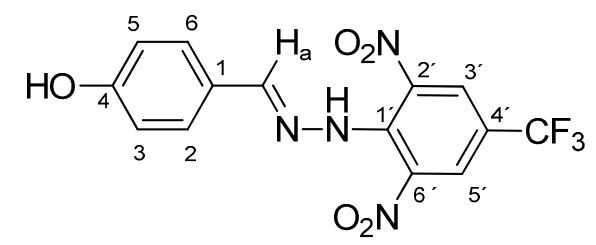

$N$-(4-Hydroxybenzylidene)- $N^{\prime}$-[2,6-dinitro-4-(trifluoromethyl)]phenylhydrazine (5a). Yield 72\%; red solid, M.p. $246-248{ }^{\circ} \mathrm{C}$, Anal. Calcd. for $\mathrm{C}_{7} \mathrm{H}_{9} \mathrm{~F}_{3} \mathrm{~N}_{4} \mathrm{O}_{5}$ (370.24) C, 45.42; $\mathrm{H}, 2.45: \mathrm{N}, 15.13$. Found: $\mathrm{C}, 45.30$; $\mathrm{H}, 2.38 ; \mathrm{N}, 15.10 \%$. IR: 3507, v(O-H); 3277, $v(\mathrm{~N}-\mathrm{H}) ; 1636, v(\mathrm{C}=\mathrm{N}) ; 1537, v_{\text {as }}\left(\mathrm{NO}_{2}\right) ; 1261, v_{\mathrm{s}}\left(\mathrm{NO}_{2}\right)$; 1125, $v\left(\mathrm{CF}_{3}\right) .{ }^{1} \mathrm{H}$ NMR $(600 \mathrm{MHz}, \mathrm{DMSO}): \delta=11.46(\mathrm{~s}, 1 \mathrm{H}, \mathrm{NH}), 10.05(\mathrm{~s}, 1 \mathrm{H}, \mathrm{OH}), 8.53(\mathrm{~s}, 2 \mathrm{H}$, H-3', H-5'), 8.41 (s, 1H, H-a), 7.39 (d, J = 8.6 Hz, 2H, H-2, H-6), 6.84 (d, J = 8.6 Hz, 2H, H-3, H-5). ${ }^{13} \mathrm{C}$ NMR (151 MHz, DMSO): $\delta=160.34,149.53,137.47,136.16,129.54,127.64$ (q, $\left.J=3.3 \mathrm{~Hz}\right), 125.11$, $123.17(\mathrm{q}, J=271.5 \mathrm{~Hz}), 116.37(\mathrm{q}, J=35.1 \mathrm{~Hz}), 116.32$; negative LC-MS $m / z: 369.0[\mathrm{M}-\mathrm{H}]^{-}$calc. for $\mathrm{C}_{7} \mathrm{H}_{8} \mathrm{~F}_{3} \mathrm{~N}_{4} \mathrm{O}_{5}{ }^{-}$, 369.045, found 369.0.

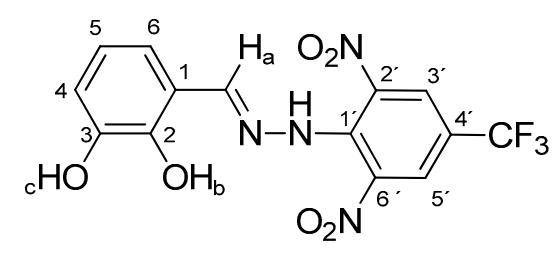

$N$-(2,3-Dihydroxybenzylidene)- $N^{\prime}$-[2,6-dinitro-4-(trifluoromethyl)]phenylhydrazine (5b). Yield 79\%; red solid, M.p. 226-228 ${ }^{\circ} \mathrm{C}$, Anal. Calcd. for $\mathrm{C}_{14} \mathrm{H}_{9} \mathrm{~F}_{3} \mathrm{~N}_{4} \mathrm{O}_{6}$ (386.24) $\mathrm{C}$, 43.54; $\mathrm{H}, 2.35: \mathrm{N}, 14.51$. Found: $\mathrm{C}, 43.64$; $\mathrm{H}, 2.39 ; \mathrm{N}, 14.63 \%$. IR: 3528, $3377 v(\mathrm{O}-\mathrm{H}) ; 3274, v(\mathrm{~N}-\mathrm{H}) ; 1633, v(\mathrm{C}=\mathrm{N}) ; 1537, v_{\mathrm{as}}\left(\mathrm{NO}_{2}\right) ; 1279, v_{\mathrm{s}}\left(\mathrm{NO}_{2}\right)$; 1125, $v\left(\mathrm{CF}_{3}\right) .{ }^{1} \mathrm{H}$ NMR $(600 \mathrm{MHz}, \mathrm{DMSO}): \delta=11.56(\mathrm{~s}, 1 \mathrm{H}, \mathrm{NH}), 9.63(\mathrm{~s}, 1 \mathrm{H}, \mathrm{OH}-\mathrm{b}), 9.03(\mathrm{~s}, 1 \mathrm{H}, \mathrm{OH}-\mathrm{c})$, 8.79 (s, 1H, H-a), 8.51 (s, 2H, H-3', H-5'), 6.93 (dd, J = 7.9, $1.5 \mathrm{~Hz}, 1 \mathrm{H}, \mathrm{H}-6), 6.81$ (dd, J = 7.9, $1.5 \mathrm{~Hz}, 1 \mathrm{H}$, H-4), 6.65 (dd, $J=7.9 \mathrm{~Hz}, 1 \mathrm{H}, \mathrm{H}-5) .{ }^{13} \mathrm{C}$ NMR (151 MHz, DMSO): $\delta=146.29,146.19,146.15,137.71$, $136.11,127.63(\mathrm{q}, J=3.4 \mathrm{~Hz}), 123.15(\mathrm{q}, J=271.4 \mathrm{~Hz}), 121.24,119.81,117.36,116.71(\mathrm{q}, J=35.4 \mathrm{~Hz})$, 116.44; negative LC-MS m/z: $385.0[\mathrm{M}-\mathrm{H}]^{-}$calc. for $\mathrm{C}_{14} \mathrm{H}_{8} \mathrm{~F}_{3} \mathrm{~N}_{4} \mathrm{O}_{6}{ }^{-}$, 385.04, found 385.0.

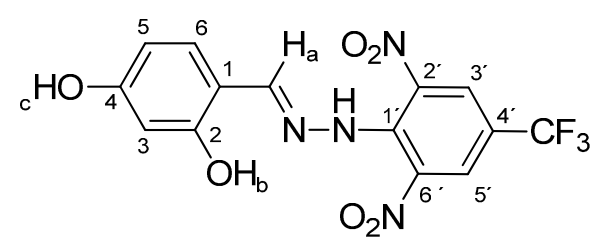

$N-(2,4-D i h y d r o x y b e n z y l i d e n e)-N^{\prime}-[2,6$-dinitro-4-(trifluoromethyl)]phenylhydrazine (5c). Yield 73\%; red solid, M.p. 229-230 ${ }^{\circ} \mathrm{C}$, Anal. Calcd. for $\mathrm{C}_{14} \mathrm{H}_{9} \mathrm{~F}_{3} \mathrm{~N}_{4} \mathrm{O}_{6}$ (386.24) $\mathrm{C}$, 43.54; $\mathrm{H}, 2.35$ : N, 14.51. Found: $\mathrm{C}, 43.66$; $\mathrm{H}, 2.24 ; \mathrm{N}, 14.40 \%$. IR: 3528, $3377 v(\mathrm{O}-\mathrm{H}) ; 3274, v(\mathrm{~N}-\mathrm{H}) ; 1633, v(\mathrm{C}=\mathrm{N}) ; 1537, v_{\text {as }}\left(\mathrm{NO}_{2}\right) ; 1279, v_{\mathrm{s}}\left(\mathrm{NO}_{2}\right)$; 
1125, $v\left(\mathrm{CF}_{3}\right) .{ }^{1} \mathrm{H}$ NMR (600 MHz, DMSO): $\delta=11.46(\mathrm{~s}, 1 \mathrm{H}, \mathrm{NH}), 9.94(\mathrm{~s}, 1 \mathrm{H}, \mathrm{OH}-\mathrm{b}), 9.88(\mathrm{~s}, 1 \mathrm{H}, \mathrm{OH}-\mathrm{c})$, $8.63(\mathrm{~s}, 1 \mathrm{H}, \mathrm{H}-\mathrm{a}), 8.48$ (s, 2H, H-3', $\left.\mathrm{H}-5^{\prime}\right), 7.27$ (d, J = 8.6 Hz, 1H, H-6), 6.31 (d, J = 2.2 Hz, 1H, H-3), $6.28(\mathrm{dd}, J=8.6,2.2 \mathrm{~Hz}, 1 \mathrm{H}, \mathrm{H}-5) .{ }^{13} \mathrm{C}$ NMR $(151 \mathrm{MHz}, \mathrm{DMSO}): \delta=161.69,158.89,146.59,137.36$, $136.07,127.82,127.67(\mathrm{q}, J=3.2 \mathrm{~Hz}), 123.20(\mathrm{q}, J=271.4 \mathrm{~Hz}), 115.93(\mathrm{q}, J=35.3 \mathrm{~Hz}), 112.09,108.66$, 102.73; negative LC-MS $m / z: 385.0[\mathrm{M}-\mathrm{H}]^{-}$calc. for $\mathrm{C}_{14} \mathrm{H}_{8} \mathrm{~F}_{3} \mathrm{~N}_{4} \mathrm{O}_{6}{ }^{-}$, 385.04, found 385.0.

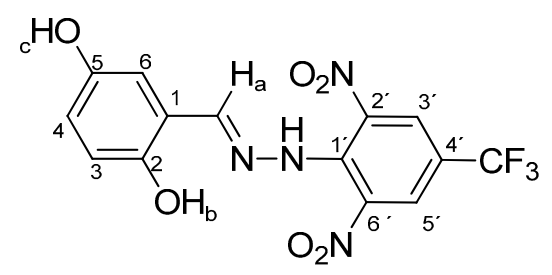

$N-(2,5-D i h y d r o x y b e n z y l i d e n e)-N$-[2,6-dinitro-4-(trifluoromethyl)]phenylhydrazine (5d). Yield 83\%; red solid, M.p. 233-234 ${ }^{\circ} \mathrm{C}$, Anal. Calcd. for $\mathrm{C}_{14} \mathrm{H}_{9} \mathrm{~F}_{3} \mathrm{~N}_{4} \mathrm{O}_{6}$ (386.24) C, 43.54; $\mathrm{H}, 2.35: \mathrm{N}, 14.51$. Found: $\mathrm{C}, 43.41$; $\mathrm{H}, 2.42 ; \mathrm{N}, 14.62 \%$. IR: 3517, $3346 v(\mathrm{O}-\mathrm{H}) ; 3257, v(\mathrm{~N}-\mathrm{H}) ; 1635, v(\mathrm{C}=\mathrm{N}) ; 1536, v_{\text {as }}\left(\mathrm{NO}_{2}\right) ; 1270, v_{\mathrm{s}}\left(\mathrm{NO}_{2}\right)$; 1129, $v\left(\mathrm{CF}_{3}\right) .{ }^{1} \mathrm{H}$ NMR $(600 \mathrm{MHz}, \mathrm{DMSO}): \delta=11.55(\mathrm{~s}, 1 \mathrm{H}, \mathrm{NH}), 9.40(\mathrm{~s}, 1 \mathrm{H}, \mathrm{OH}-\mathrm{b}), 8.95(\mathrm{~s}, 1 \mathrm{H}$, OH-c), 8.73 (s, 1H, H-a), 8.54 (s, 2H, H-3' , H-5'), 6.85 (d, J = $2.1 \mathrm{~Hz}, 1 \mathrm{H}, \mathrm{H}-6), 6.73$ (s, 2H, H-4, H-3). ${ }^{13} \mathrm{C}$ NMR (151 MHz, DMSO): $\delta=150.42,150.34,146.27,137.74,136.10,127.64(\mathrm{q}, J=3.5 \mathrm{~Hz})$, $123.15(\mathrm{q}, J=271.6 \mathrm{~Hz}), 120.70,120.21,117.42,116.71(\mathrm{q}, J=35.3 \mathrm{~Hz}), 111.37$; negative LC-MS $\mathrm{m} / \mathrm{z}: 385.1$ $[\mathrm{M}-\mathrm{H}]^{-}$calc. for $\mathrm{C}_{14} \mathrm{H}_{8} \mathrm{~F}_{3} \mathrm{~N}_{4} \mathrm{O}_{6}{ }^{-}$, 385.04, found 385.1.

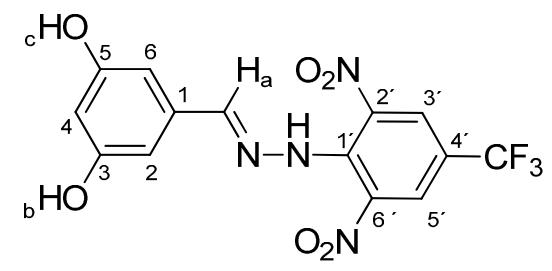

N-(3,5-Dihydroxybenzylidene)-N'-[2,6-dinitro-4-(trifluoromethyl)]phenylhydrazine (5e). Yield 78\%; red solid, M.p. 264-266 ${ }^{\circ} \mathrm{C}$, Anal. Calcd. for $\mathrm{C}_{14} \mathrm{H}_{9} \mathrm{~F}_{3} \mathrm{~N}_{4} \mathrm{O}_{6}$ (386.24) C, 43.54; $\mathrm{H}, 2.35: \mathrm{N}, 14.51$. Found: $\mathrm{C}, 43.66$; $\mathrm{H}, 2.23$; N $14.38 \%$. IR: 3539, $3347 v(\mathrm{O}-\mathrm{H}) ; 3270, v(\mathrm{~N}-\mathrm{H}) ; 1637, v(\mathrm{C}=\mathrm{N}) ; 1536, v_{\mathrm{as}}\left(\mathrm{NO}_{2}\right) ; 1268, v_{\mathrm{s}}\left(\mathrm{NO}_{2}\right)$; 1126, $v\left(\mathrm{CF}_{3}\right) .{ }^{1} \mathrm{H}$ NMR $(300 \mathrm{MHz}, \mathrm{DMSO}): \delta=11.45(\mathrm{~s}, 1 \mathrm{H}, \mathrm{NH}), 9.49(\mathrm{~s}, 2 \mathrm{H}, \mathrm{OH}-\mathrm{b}, \mathrm{OH}-\mathrm{c})$, $8.55\left(\mathrm{~s}, 2 \mathrm{H}, \mathrm{H}-3^{\prime}, \mathrm{H}-5^{\prime}\right), 8.34(\mathrm{~s}, 1 \mathrm{H}, \mathrm{H}-\mathrm{a}), 6.42(\mathrm{~d}, J=2.1 \mathrm{~Hz}, 2 \mathrm{H}, \mathrm{H}-2, \mathrm{H}-6), 6.32(\mathrm{dd}, J=2.1 \mathrm{~Hz}$, $1 \mathrm{H}, \mathrm{H}-4) .{ }^{13} \mathrm{C}$ NMR $(75 \mathrm{MHz}, \mathrm{DMSO}): \delta=158.63,149.63,137.33,135.66,135.20,127.19(\mathrm{q}, J=17.8 \mathrm{~Hz})$, $122.67(\mathrm{q}, J=271.5 \mathrm{~Hz}), 116.60(\mathrm{q}, J=35.4 \mathrm{~Hz}), 105.48,105.01$; negative LC-MS $m / z: 385.0[\mathrm{M}-\mathrm{H}]^{-}$ calc. for $\mathrm{C}_{14} \mathrm{H}_{8} \mathrm{~F}_{3} \mathrm{~N}_{4} \mathrm{O}_{6}{ }^{-}$, 385.04, found 385.0.<smiles>C/C(=N\Nc1c([N+](=O)[O-])cc(C(F)(F)F)cc1[N+](=O)[O-])c1ccc(O)c(O)c1O</smiles>

N-(2,3,4-Dihydroxybenzylidene)-N'-[2,6-dinitro-4-(trifluoromethyl)]phenylhydrazine (5f). Yield 85\%; red solid, M.p. 232-233 ${ }^{\circ} \mathrm{C}$, Anal. Calcd. for $\mathrm{C}_{14} \mathrm{H}_{9} \mathrm{~F}_{3} \mathrm{~N}_{4} \mathrm{O}_{7}(402.24) \mathrm{C}, 41.80 ; \mathrm{H}, 2.26$ : $\mathrm{N}, 13.93$. Found: $\mathrm{C}, 41.70$; $\mathrm{H}, 2.18 ; \mathrm{N}, 14.05 \%$. IR: 3532, 3481, $3359 v(\mathrm{O}-\mathrm{H}) ; 3272, v(\mathrm{~N}-\mathrm{H}) ; 1633, v(\mathrm{C}=\mathrm{N}) ; 1530, v_{\text {as }}\left(\mathrm{NO}_{2}\right)$; $1269, v_{\mathrm{s}}\left(\mathrm{NO}_{2}\right) ; 1128, v\left(\mathrm{CF}_{3}\right) .{ }^{1} \mathrm{H}$ NMR $(300 \mathrm{MHz}, \mathrm{DMSO}): \delta=11.48(\mathrm{~s}, 1 \mathrm{H}, \mathrm{NH}), 9.70(\mathrm{~s}, 1 \mathrm{H}, \mathrm{OH}-\mathrm{b})$, $9.03(\mathrm{~s}, 1 \mathrm{H}, \mathrm{OH}-\mathrm{d}), 8.67$ (s, 1H, OH-c), $8.54(\mathrm{~s}, 1 \mathrm{H}, \mathrm{H}-\mathrm{a}), 8.50\left(\mathrm{~s}, 2 \mathrm{H}, \mathrm{H}-3^{\prime}, \mathrm{H}-5^{\prime}\right), 6.85$ (d, J = $8.6 \mathrm{~Hz}$, $1 \mathrm{H}, \mathrm{H}-6), 6.37$ (d, $J=8.6 \mathrm{~Hz}, 1 \mathrm{H}, \mathrm{H}-5) .{ }^{13} \mathrm{C}$ NMR $(151 \mathrm{MHz}, \mathrm{DMSO}): \delta=160.34,149.53,137.47,136.16$, $129.54,127.64(\mathrm{q}, J=3.3 \mathrm{~Hz}), 125.11,123.17(\mathrm{q}, J=271.5 \mathrm{~Hz}), 116.37(\mathrm{q}, J=35.1 \mathrm{~Hz}), 116.32$; negative LC-MS $m / z: 401.0[\mathrm{M}-\mathrm{H}]^{-}$calc. for $\mathrm{C}_{14} \mathrm{H}_{8} \mathrm{~F}_{3} \mathrm{~N}_{4} \mathrm{O}_{7}{ }^{-}, 401.035$, found 401.0. 


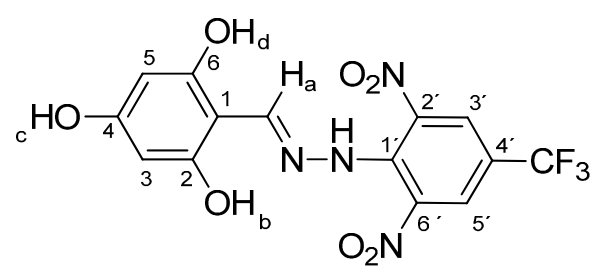

$N-(2,4,6$-Dihydroxybenzylidene)-N'-[2,6-dinitro-4-(trifluoromethyl)]phenylhydrazine (5g). Yield 84\%; red solid, M.p. 238-240 ${ }^{\circ} \mathrm{C}$, Anal. Calcd. for $\mathrm{C}_{14} \mathrm{H}_{9} \mathrm{~F}_{3} \mathrm{~N}_{4} \mathrm{O}_{7}$ (402.24) C, 41.80; $\mathrm{H}, 2.26: \mathrm{N}, 13.93$. Found: $\mathrm{C}, 41.96$; $\mathrm{H}, 2.30 ; \mathrm{N}, 13.80 \%$. IR: $3323 v(\mathrm{O}-\mathrm{H}) ; 3262, v(\mathrm{~N}-\mathrm{H}) ; 1633, v(\mathrm{C}=\mathrm{N}) ; 1532, v_{\mathrm{as}}\left(\mathrm{NO}_{2}\right) ; 1263, v_{\mathrm{s}}\left(\mathrm{NO}_{2}\right)$; 1126, $v\left(\mathrm{CF}_{3}\right) .{ }^{1} \mathrm{H}$ NMR $(300 \mathrm{MHz}, \mathrm{DMSO}): \delta=11.44(\mathrm{~s}, 1 \mathrm{H}, \mathrm{NH}), 10.02(\mathrm{~s}, 1 \mathrm{H}, \mathrm{OH}-\mathrm{c}), 9.83(\mathrm{~s}, 2 \mathrm{H}, \mathrm{OH}-\mathrm{b}$, OH-d), 8.89 (s, 1H, H-a), 8.54 (s, 2H, H-3' , H-5'), 5.86 (s, 2H, H-3, H-5). ${ }^{13} \mathrm{C}$ NMR (75 MHz, DMSO): $\delta=162.57,159.57,150.75(\mathrm{q}, J=14.5 \mathrm{~Hz}), 137.13,135.08,127.72(\mathrm{q}, J=18.9 \mathrm{~Hz}), 122.68(\mathrm{q}, J=271.5 \mathrm{~Hz})$, $115.91(\mathrm{q}, J=35.4 \mathrm{~Hz}), 98.57,94.47$; negative LC-MS $m / z: 401.0[\mathrm{M}-\mathrm{H}]^{-}$calc. for $\mathrm{C}_{14} \mathrm{H}_{8} \mathrm{~F}_{3} \mathrm{~N}_{4} \mathrm{O}_{7}{ }^{-}$, 401.035, found 401.0.

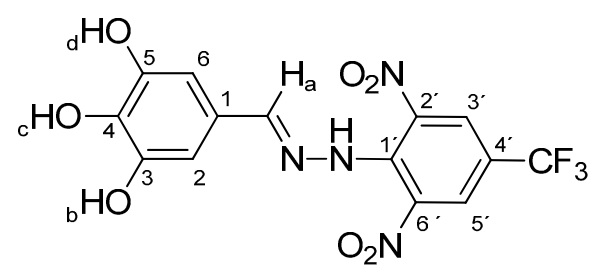

$N$-(3,4,5-Trihydroxybenzylidene)- $N^{\prime}$-[2,6-dinitro-4-(trifluoromethyl)]phenylhydrazine (5h). Yield 71\%; red solid, M.p. 279-280 ${ }^{\circ} \mathrm{C}$, Anal. Calcd. for $\mathrm{C}_{14} \mathrm{H}_{9} \mathrm{~F}_{3} \mathrm{~N}_{4} \mathrm{O}_{7}(402.24) \mathrm{C}, 41.80 ; \mathrm{H}, 2.26: \mathrm{N}, 13.93$. Found: $\mathrm{C}, 41.62$; $\mathrm{H}, 2.15 ; \mathrm{N}, 13.80 \%$. IR: $3428 v(\mathrm{O}-\mathrm{H}) ; 3266, v(\mathrm{~N}-\mathrm{H}) ; 1634, v(\mathrm{C}=\mathrm{N}) ; 1537, v_{\mathrm{as}}\left(\mathrm{NO}_{2}\right) ; 1265, v_{\mathrm{s}}\left(\mathrm{NO}_{2}\right)$; 1125, $v\left(\mathrm{CF}_{3}\right) .{ }^{1} \mathrm{H}$ NMR $(300 \mathrm{MHz}, \mathrm{DMSO}): \delta=11.37(\mathrm{~s}, 1 \mathrm{H}, \mathrm{NH}), 9.15(\mathrm{~s}, 2 \mathrm{H}, \mathrm{OH}-\mathrm{b}, \mathrm{OH}-\mathrm{d})$, 8.78 (s, 1H, OH-c), 8.53 (s, 2H, H-3', $\left.\mathrm{H}-5^{\prime}\right), 8.26$ (s, 1H, H-a), 6.53 (s, 2H, H-2, H-6). ${ }^{13} \mathrm{C}$ NMR (75 MHz, DMSO): $\delta=150.27,146.09,137.01,136.57,135.66,127.23(\mathrm{q}, J=3.5 \mathrm{~Hz}), 123.76,122.73(\mathrm{q}, J=271.5 \mathrm{~Hz})$, $115.82(\mathrm{q}, J=35.4 \mathrm{~Hz}), 106.85$; negative LC-MS $m / z: 401.0[\mathrm{M}-\mathrm{H}]^{-}$calc. for $\mathrm{C}_{14} \mathrm{H}_{8} \mathrm{~F}_{3} \mathrm{~N}_{4} \mathrm{O}_{7}{ }^{-}, 401.035$, found 401.0.

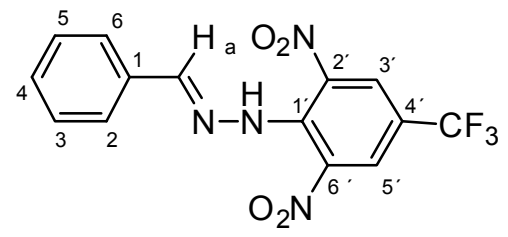

$\mathrm{N}$-(Benzylidene)-N'-[2,6-dinitro-4-(trifluoromethyl)]phenylhydrazine (5i). Yield 70\%; red solid, M.p. $231-232{ }^{\circ} \mathrm{C}$, Anal. Calcd. for $\mathrm{C}_{14} \mathrm{H}_{9} \mathrm{~F}_{3} \mathrm{~N}_{4} \mathrm{O}_{4}$ (354.24) C, 47.47; H, 2.56: N, 15.82. Found: C, 47.65; H, 2.48; N, 15.71\%. IR: 3265, $v(\mathrm{~N}-\mathrm{H}) ; 1631, v(\mathrm{C}=\mathrm{N}) ; 1538, v_{\mathrm{as}}\left(\mathrm{NO}_{2}\right) ; 1267, v_{\mathrm{s}}\left(\mathrm{NO}_{2}\right) ; 1121, v\left(\mathrm{CF}_{3}\right) .{ }^{1} \mathrm{H}$ NMR $(600 \mathrm{MHz}$, DMSO): $\delta=11.57(\mathrm{~s}, 1 \mathrm{H}, \mathrm{NH}), 8.57$ (s, 2H, H-3' $\left.\mathrm{H}^{\prime} 5^{\prime}\right), 8.53(\mathrm{~s}, 1 \mathrm{H}, \mathrm{H}-\mathrm{a}), 7.55(\mathrm{dd}, J=7.7,1.4 \mathrm{~Hz}, 2 \mathrm{H}$, H-2, H-6), $7.50-7.42$ (m, 3H, H-3, H-4, H-5). ${ }^{13} \mathrm{C}$ NMR (151 MHz, DMSO): $\delta=149.02,137.84,136.05$, $134.15,130.94,129.44,127.64(\mathrm{q}, J=3.4 \mathrm{~Hz}), 127.58,123.10(\mathrm{q}, J=271.6 \mathrm{~Hz}), 117.29(\mathrm{q}, J=35.3 \mathrm{~Hz})$; negative LC-MS $m / z: 353.0$ [M - H] $]^{-}$calc. for $\mathrm{C}_{14} \mathrm{H}_{9} \mathrm{~F}_{3} \mathrm{~N}_{4} \mathrm{O}_{4}{ }^{-}$, 353.05, found 353.0.

\subsection{Free Radical Scavenging Activity Assay}

The free radical scavenging activity of the prepared hydroxybenzylidene hydrazines was carried out according to our previous work [25]. Various amounts of tested compounds were added into a methanol solution of DPPH or GOR and the final DPPH or GOR concentration was kept constant $\left(c=10^{-4} \mathrm{~mol} \cdot \mathrm{dm}^{-3}\right)$ or into a water solution of ABTS. The free radical scavenging activity was evaluated using the values $\mathrm{SC}_{50}$, i.e., the concentration of the studied compound, which causes 
a 50\% decrease in absorbance at $517 \mathrm{~nm}$ (for DPPH), $862 \mathrm{~nm}$ (for GOR), or $734 \mathrm{~nm}$ (for ABTS) as compared to the control sample. Methanol or water was used as a blank. All samples were measured in triplicate. Standard square deviations were in a range from 0.91 to 0.99.

\subsection{Photosynthetic Electron Transport (PET) Study}

PET was monitored in spinach chloroplasts prepared according to our previous work $[4,27]$. PET through PSII was monitored by the Hill reaction with DCPIP as an artificial electron acceptor. DCPIP photoreduction was determined spectrophotometrically. The chlorophyll (Chl) concentration in these experiments was $30 \mathrm{mg} / \mathrm{dm}^{3}$. The inhibitory activities of the studied compounds were expressed by $\mathrm{IC}_{50}$ values, i.e., molar concentrations of the compounds causing a $50 \%$ decrease of absorbance at $600 \mathrm{~nm}$ compared to the control sample. Each sample was measured in triplicate and standard square deviations were in the $0.88-0.94$ range.

\subsection{Molecular Calculations}

The prepared hydroxybenzylidene hydrazines, their anions and radicals were studied using the quantum chemical method PM6 [28], which is part of the program MOPAC2012 [29]. Optimal structures of compounds were calculated (keyword PRECISE). The effect of solvents on the above mentioned compounds were studied by COSMO-method [30], which is also part of MOPAC2012 [31]. Ionization potentials and enthalpy of formations used for the calculation of PDE, BDE, PA, and ETE according to our previous work [25].

Supplementary Materials: The following are available online: Table S1: Proton dissociation energy of prepared $N$-hydroxybenzylidene hydrazines in methanol; Table S2: Dissociation energy of hydrogen and electron of prepared $\mathrm{N}$-hydroxybenzylidene hydrazines in methanol; Table S3: Proton affinity of prepared $N$-hydroxybenzylidene hydrazines in methanol; Table S4: Electron transfer enthalpy of prepared $N$-hydroxybenzylidene hydrazines in methanol; Table S5: Proton dissociation energy of prepared $N$-hydroxybenzylidene hydrazines in water; Table S6: Dissociation energy of hydrogen and electron of prepared N-hydroxybenzylidene hydrazines in water; Table S7: Proton affinity of prepared N-hydroxybenzylidene hydrazines in water; Table S8: Electron transfer enthalpy of prepared $N$-hydroxybenzylidene hydrazines in water.

Acknowledgments: This work was supported by the Austrian Science Fund (FWF): (P23609, P21437, and F34), the Slovak Grant Agency VEGA (1/0196/14) and by the European Community's Seventh Framework Programme (FP7/2007-2013) under grant agreement number PCIG11-GA-2012-322300. We want to thank our colleagues from the Department of Chemistry, Faculty of Natural Sciences, Matej Bell University for measuring IR spectra and from the Research Institute of Molecular Pathology, Vienna, Austria, for their support.

Author Contributions: F.S., F.G. and P.K. performed experiments. F.S., F.G., J.K., J.F., D.L. and J.G. analyzed results and wrote the manuscript. All authors contributed to the paper and approved the manuscript.

Conflicts of Interest: The authors declare no conflict of interest.

\section{References}

1. Backes, G.L.; Neumann, D.M.; Jursic, B.S. Synthesis and antifungal activity of substituted salicylaldehyde hydrazones, hydrazides and sulfohydrazides. Bioorg. Med. Chem. 2014, 22, 4629-4636. [CrossRef] [PubMed]

2. Dabideen, D.R.; Cheng, K.F.; Aljabari, B.; Miller, E.J.; Pavlov, V.A.; Al-Abed, Y. Phenolic hydrazones are potent inhibitors of macrophage migration inhibitory factor proinflammatory activity and survival improving agents in sepsis. J. Med. Chem. 2007, 50, 1993-1997. [CrossRef] [PubMed]

3. Gadilohar, B.; Shankarling, G. Choline based ionic liquids and their applications in organic transformation. J. Mol. Liq. 2007, 227, 234-261. [CrossRef]

4. Sersen, F.; Gregan, F.; Pesko, M.; Dvoranova, D.; Kralova, K.; Matkovicova, Z.; Gregan, J.; Donovalova, J. Synthesis and herbicidal activity of new hydrazide and hydrazonoyl derivatives. Molecules 2015, 20, 14139-14154. [CrossRef] [PubMed]

5. Rollas, S.; Kucukguzel, S.G. Biological activities of hydrazone derivatives. Molecules 2007, 12, $1910-1939$. [CrossRef] [PubMed]

6. Narang, R.; Narasimhan, B.; Sharma, S. A review on biological activities and chemical synthesis of hydrazide derivatives. Curr. Med. Chem. 2012, 19, 569-612. [CrossRef] [PubMed] 
7. Cheng, L.X.; Tang, J.J.; Luo, H.; Jin, X.L.; Dai, F.; Yang, J.; Qian, Y.P.; Li, X.Z.; Zhou, B. Antioxidant and antiproliferative activities of hydroxyl-substituted Schiff bases. Bioorg. Med. Chem. Lett. 2010, 20, 2417-2420. [CrossRef] [PubMed]

8. Torok, B.; Sood, A.; Bag, S.; Tulsan, R.; Ghosh, S.; Borkin, D.; Kennedy, A.R.; Melanson, M.; Madden, R.; Zhou, W.; et al. Diaryl hydrazones as multifunctional inhibitors of amyloid self-assembly. Biochemistry 2013, 52, 1137-1148. [CrossRef] [PubMed]

9. El-Sayed, N.N.; Alafeefy, A.M.; Bakht, M.A.; Masand, V.H.; Aldalbahi, A.; Chen, N.; Fan, C.; Ben Bacha, A. Synthesis, antiphospholipase A(2), antiprotease, antibacterial evaluation and molecular docking analysis of certain novel hydrazones. Molecules 2016, 21, 1664. [CrossRef] [PubMed]

10. El-Faham, A.; Farooq, M.; Khattab, S.N.; Abutaha, N.; Wadaan, M.A.; Ghabbour, H.A.; Fun, H.K. Synthesis, characterization, and anti-cancer activity of some new $N^{\prime}$-(2-Oxoindolin-3-ylidene)-2-propylpentane hydrazide-hydrazones derivatives. Molecules 2015, 20, 14638-14655. [CrossRef] [PubMed]

11. Casanova, B.B.; Muniz, M.N.; de Oliveira, T.; de Oliveira, L.F.; Machado, M.M.; Fuentefria, A.M.; Gosmann, G.; Gnoatto, S.C. Synthesis and biological evaluation of hydrazone derivatives as antifungal agents. Molecules 2015, 20, 9229-9241. [CrossRef] [PubMed]

12. Toledano-Magana, Y.; Garcia-Ramos, J.C.; Navarro-Olivarria, M.; Flores-Alamo, M.; Manzanera-Estrada, M.; Ortiz-Frade, L.; Galindo-Murillo, R.; Ruiz-Azuara, L.; Melendrez-Luevano, R.M.; Cabrera-Vivas, B.M. Potential amoebicidal activity of hydrazone derivatives: synthesis, characterization, electrochemical behavior, theoretical study and evaluation of the biological activity. Molecules 2015, 20, 9929-9948. [CrossRef] [PubMed]

13. La Regina, G.; Sarkar, T.; Bai, R.; Edler, M.C.; Saletti, R.; Coluccia, A.; Piscitelli, F.; Minelli, L.; Gatti, V.; Mazzoccoli, C.; et al. New arylthioindoles and related bioisosteres at the sulfur bridging group. 4. Synthesis, tubulin polymerization, cell growth inhibition, and molecular modeling studies. J. Med. Chem. 2009, 52, 7512-7527. [CrossRef] [PubMed]

14. Silvestri, R.; Cascio, M.G.; La Regina, G.; Piscitelli, F.; Lavecchia, A.; Brizzi, A.; Pasquini, S.; Botta, M.; Novellino, E.; Di Marzo, V.; et al. Synthesis, cannabinoid receptor affinity, and molecular modeling studies of substituted 1-aryl-5-(1H-pyrrol-1-yl)-1H-pyrazole-3-carboxamides. J. Med. Chem. 2008, 51, 1560-1576. [CrossRef] [PubMed]

15. Baratto, L.C.; Porsani, M.V.; Pimentel, I.C.; Pereira Netto, A.B.; Paschke, R.; Oliveira, B.H. Preparation of betulinic acid derivatives by chemical and biotransformation methods and determination of cytotoxicity against selected cancer cell lines. Eur. J. Med. Chem. 2013, 68, 121-131. [CrossRef] [PubMed]

16. Singh, R.K.; Singh, A.K. DFT calculations on molecular structure, spectral analysis, multiple interactions, reactivity, NLO property and molecular docking study of flavanol-2,4-dinitrophenylhydrazone. J. Mol. Struct. 2017, 1129, 128-141. [CrossRef]

17. Parodi, S.; de Flora, S.; Cavanna, M.; Pino, A.; Robbiano, L.; Bennicelli, C.; Brambilla, G. DNA-damaging activity in vivo and bacterial mutagenicity of sixteen hydrazine derivatives as related quantitatively to their carcinogenicity. Cancer Res. 1981, 41, 1469-1482. [PubMed]

18. Heath, R.L. Hydrazine as an electron donor to the water-oxidation site in photosynthesis. Biochim. Biophys. Acta 1971, 245, 160-164. [CrossRef]

19. Messinger, J.; Renger, G. Generation, oxidation by the oxidized form of the tyrosine of polypeptide D2, and possible electronic configuration of the redox states S0, S-1, and S-2 of the water oxidase in isolated spinach thylakoids. Biochemistry 1993, 32, 9379-9386. [CrossRef] [PubMed]

20. Forster, V.; Junge, W. On the action of hydroxylamine, hydrazine and their derivatives on the water-oxidizing complex. Photosynth. Res. 1986, 9, 197-210. [CrossRef] [PubMed]

21. Messinger, J.; Renger, G. The reactivity of hydrazine with photosystem II strongly depends on the redox state of the water oxidizing system. FEBS Lett. 1990, 277, 141-146. [CrossRef]

22. Crampton, M.R.; Khan, H.A. The stabilities of meisenheimer complexes. J. Chem. Soc. Perkin Trans. 1972, 2, 1173-1177. [CrossRef]

23. Sakamoto, H.; Goto, H.; Yokoshima, M.; Dobashi, M.; Ishikawa, J.; Doi, K.; Otomo, M. Benzocrown ether hydrazones as extractants for alkali metal ions. Bull. Chem. Soc. Jpn. 1993, 66, 2907-2914. [CrossRef]

24. Sersen, F.; Mucaji, P.; Spilkova, J.; Valko, V.; Haladova, M.; Eisenreichova, E.; Grancai, D. Antioxidative effectivness of various solvent extracts from leaves of Cynara cardunculus, Philadelphus coronarius, Lilium candidum, Holodiscus discolor and Ligustrum vulgare. Acta Fac. Pharm. Univ. Comen. 2006, 53, 262-267. 
25. Kotora, P.; Sersen, F.; Filo, J.; Loos, D.; Gregan, J.; Gregan, F. The scavenging of DPPH, galvinoxyl and ABTS radicals by imine analogs of resveratrol. Molecules 2016, 21, 127. [CrossRef] [PubMed]

26. Sersen, F.; Lacova, M. Antioxidant activity of some coumarins. Acta Fac. Pharm. Univ. Comen. 2015, 62, 41-45.

27. Dolezal, M.; Miletin, M.; Kunes, J.; Kralova, K. Substituted amides of pyrazine-2-carboxylic acids: synthesis and biological activity. Molecules 2002, 7, 363-373. [CrossRef]

28. Stewart, J.J. Optimization of parameters for semiempirical methods V: Modification of NDDO approximations and application to 70 elements. J. Mol. Model. 2007, 13, 1173-1213. [CrossRef] [PubMed]

29. Stewart, J.J.P. MOPAC, version 2012; Stewart Computational Chemistry: Colorado Springs, CO, USA, 2012. Available online: http:/ / openmopac.net/MOPAC2012brochure.pdf.

30. Klamt, A.; Schüürmann, G. COSMO: A new approach to dielectric screening in solvents with explicit expressions for the screening energy and its gradient. J. Chem. Soc. Perkin Trans. 2 1993, 5, 799-805. [CrossRef]

31. MOPAC Manual. Available online: http://OpenMOPAC.net/Manual (accessed on 10 January 2015).

Sample Availability: Samples of the compounds are not available from the authors.

(C) 2017 by the authors. Licensee MDPI, Basel, Switzerland. This article is an open access article distributed under the terms and conditions of the Creative Commons Attribution (CC BY) license (http:/ / creativecommons.org/licenses/by/4.0/). 